\section{MODULATION OF ALLOREACTIVITY IN TRANSPLANT RECIPIENTS BY PHENOTYPIC MANIPULATION OF DONOR ENDOTHELIUM}

Phenotypic manipulation of allograft endothelium to reduce immunogenicity would have a significant impact on transplantation. In this study we have demonstrated that random seeding of a heart allograft with endothelium, of host origin, not only promotes long-term survival, but reduces the requirement for pharmacologic immunosuppression. We propose that this simple technology could easily be extrapolated to the clinical arena where hypothermia and preservation solutions have allowed allografts to remain ex vivo for extended periods. (J THORAC Cardiovasc Surg 1995;109:905-9)

R. L. Quigley, MD, DPhil, ${ }^{\text {a }}$ S. S. Switzer, BS, ${ }^{a}$ T. A. Victor, MD,

R. A. Goldschmidt, MD, ${ }^{b}$ M. H. Salinger, MD, ${ }^{c}$ C. E. Arentzen, MD, ${ }^{a}$

J. C. Alexander, MD, ${ }^{a}$ and R. W. Anderson, MD, ${ }^{a}$ Evanston, Ill.
$\mathrm{D}$ isparity in the major histocompatibility complex (MHC) between the donor and the recipient defines a significant component of transplant allorejection. Although nonspecific pharmacologic immunosuppression of the host has facilitated cell migration, chimerism, and graft acceptance, these drugs have also caused significant morbidity including neoplasia and infection. ${ }^{1-3}$ The endothelium of the transplant vasculature is the interface between an allograft and the host immune system. As such, it represents the target cell of early rejection. ${ }^{4}$ Reduction of the immunogenicity of endothelium by downregulation of the expression of MHC class II genes is not yet possible. However, in this report, we have shown that random seeding of a rodent heart allograft with endothelium of recipient origin not only phenotypically modifies the donor endothelium but facilitates long-term survival. This simple technique, which has implications in both allotransplantation and xenotransplantation, results in a significant reduction in the requirement of immunosuppressive therapy.

\section{Material and methods}

Preparation of endothelial cells. Rat endothelial cells were harvested from the epididymal fat pads of LewisRT1 $^{1}$ (Lew) retired breeders (Harlan Sprague-Dawley, Indianapolis, Ind.) and placed in a $0.1 \%$ bovine serum

From the Departments of Surgery, ${ }^{a}$ Pathology, ${ }^{b}$ and Medicine, ${ }^{c}$ Northwestern University-Evanston Hospital, Evanston, Ill.

Received for publication June 23, 1994.

Accepted for publication Oct. 6, 1994.

Address for reprints: R. L. Quigley, MD, DPhil, Department of Surgery-Cardiothoracic Division, Evanston Hospital, Room 100-Burch Building, 2650 Ridge Ave., Evanston, IL 60201.

Copyright 1995 by Mosby-Year Book, Inc.

$0022-5223 / 95 \$ 3.00+0 \quad \mathbf{1 2 / 1 / 6 1 1 3 6}$ albumin solution. A $2 \mathrm{mg} / \mathrm{ml}$ concentration of collagenase A (Boehringer Mannheim, Indianapolis, Ind.) was used to digest the microvasculature of the tissue. The remaining cells underwent centrifugation through a Percoll gradient (Pharmacia, Uppsala, Sweden) at $30,000 \mathrm{rpm}$ for 30 minutes. A small proportion of cells were stained with 5 $\mu \mathrm{l} / 10^{6}$ cells of endothelial cell marker (Serotec, Oxford, England) to verify cell type. The endothelial cells were then cultured in a DMEM-10 medium (DMEM, 10\% fetal bovine serum, L-glutamine $1.7 \mathrm{mmol} / \mathrm{L}$ [Gibco, Grand Island, N.Y.], crude endothelial growth factor $40 \mu \mathrm{g} / \mathrm{ml}$ [Collaborative Biomedical Products, Bedford, Mass.], and heparin $5 \mathrm{U} / \mathrm{ml}, 1 \times$ of $1 \mathrm{~mol} / \mathrm{L}$ HEPES buffer solution [Gibco]). Cells were cultured at $37^{\circ} \mathrm{C}$ for 3 days in $75 \mathrm{ml}$ Costar flasks (Cambridge, Mass.) before experimental use.

Perfusion of endothelial cells into donor allografts. The heart of the Lewis-Brown Norway $F_{1}$ rat was harvested and maintained on a modified Langendorff perfusion apparatus ${ }^{5}$ in which the heart was continually perfused with a calcium-free Krebs-Henseleit buffer, 95\% oxygen, and $5 \%$ carbon dioxide at $4^{\circ} \mathrm{C}$. The cultured endothelial cells at a concentration of $3 \times 10^{6}$ in $5 \mathrm{ml}$ of buffer were perfused randomly into the coronary ostia over 20 minutes.

Heterotopic cardiac transplantation. Donor hearts were harvested from 250 to $300 \mathrm{gm}$ male Lew $\times$ Brown Norway $-\mathrm{RT}^{\mathrm{n}}(\mathrm{BN}) \mathrm{F}_{1}$ hybrid rats. After cell perfusion they were heterotopically transplanted into 250 to $300 \mathrm{gm}$ male Lew recipients by the technique of Ono and Lindsey. ${ }^{6}$ In brief, the graft was implanted to the abdominal great vessels. Ischemic time averaged 25 minutes. Each graft was evaluated by abdominal palpation. All animals received humane care in compliance with the "Principles of Laboratory Animal Care" formulated by the National Society for Medical Research and the "Guide for the Care and Use of Laboratory Animals" prepared by the Institute of Laboratory Animal Resources and published by the National Institutes of Health (NIH Publication No. 86-23, revised 1985 ).

Mixed lymphocyte cultures. Mixed lymphocyte cultures were performed in 96 well round-bottomed microtitre plates (Costar). Viable responding cells $\left(4 \times 10^{5}\right.$ cells per well) of mesenteric lymph node origin were cultured with 


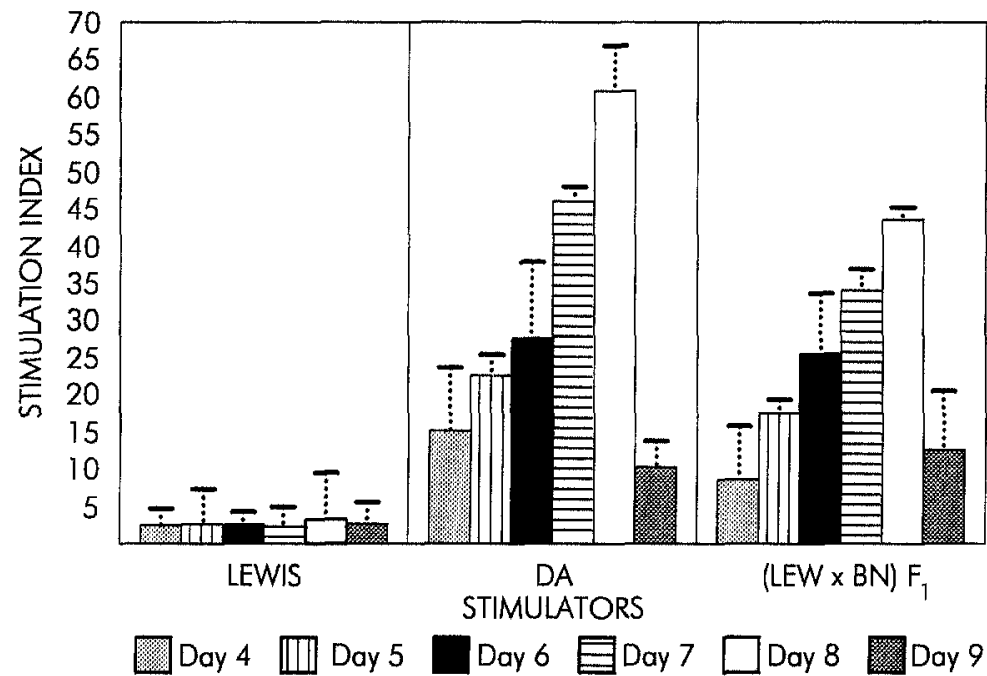

2

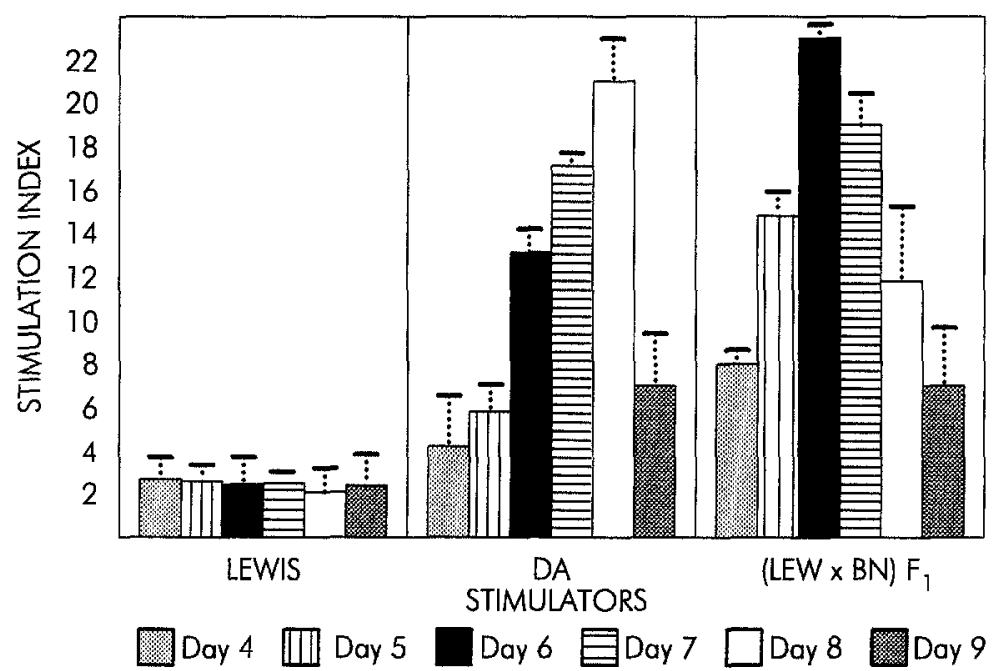

Figs. 1 and 2. Mixed lymphocyte cultures. The proliferative response of mesenteric lymph node cells (LN) harvested from untreated Lewis $\left(\mathrm{RT} 1^{1}\right)$ (Lew) rats (Fig. 1) and transplanted Lew rats (Fig. 2). Stimulation is provided by $x$-irradiated (2000R) LN cells of Lew $\times$ Brown Norway $\left(R T 1^{\mathrm{n}}\right)(\mathrm{BN}) \mathrm{F}_{1}$, Dark Agouti (DA) $\left(\mathrm{RT}^{\text {av1 }}\right)$, and Lew $\left(\mathrm{RT}^{1}\right)$ rats. Cultures were set up in triplicate with a responder:stimulator ratio of 1:1 $(n=3)$ over 9 days. The stimulation index on the ordinate axis reflects the cpm of the responders + stimulators/responders alone. The range (error bars) was calculated for each day. $P$ values were obtained by comparing $\left[{ }^{3} \mathrm{H}\right]$ thymidine uptake in cells from one day to the next. The Mann-Whitney $U$ test was used for all of these comparisons.

irradiated $(2000 \mathrm{rad})$ viable lymph node stimulator cells $\left(4 \times 10^{5}\right.$ cells per well), in a total volume of $0.2 \mathrm{ml}$ Excell 5 solution (Excell $320,20 \mathrm{ml}$ supplement, $5 \%$ fetal calf serum, 2-mercaptoethanol $2.5 \times 10^{5} \mathrm{~mol} / \mathrm{L}$, penicillin 100 $\mathrm{U} / \mathrm{ml}$, and streptomycin $100 \mathrm{mg} / \mathrm{ml}$ ) in triplicate. The plates were incubated for 9 days at $37^{\circ} \mathrm{C}$ in $5 \%$ carbon dioxide and humidified air. For each assay six identical trays were set up so that cell proliferation could be assessed over a 9-day period. One tray was pulsed with 1 $\mu \mathrm{Ci}$ of $\left[{ }^{3} \mathrm{H}\right]$ thymidine per well each day, beginning 4 days after the assays were set up. The time of the addition of $\left[{ }^{3} \mathrm{H}\right]$ thymidine is reported in Figs. 1 and 2. Cells were harvested onto filter paper using a PHD harvester (Cambridge Technology Inc., Watertown, Mass.) after a further culture of 6 hours. $\left[{ }^{3} \mathrm{H}\right]$ thymidine incorporation was evaluated in a Beckman liquid scintillation counter (Beckman Instruments, Inc., Fullerton, Calif.) (2 minutes per sample, with a toluene-based scintillant). 
Table I. Survival of Lew $\times B N F_{1}$ (donor) cardiac allografts in treated and untreated Lew (recipient) rats

\begin{tabular}{cccccc}
\hline $\begin{array}{c}\text { Perfusion donor } \\
\text { heart }\end{array}$ & $\begin{array}{c}\text { Endothelial cells } \\
\text { perfused }\end{array}$ & $\begin{array}{c}\text { Heart } \\
\text { donor }\end{array}$ & $\begin{array}{c}\text { Heart } \\
\text { recipient }\end{array}$ & Immunotherapy & Mean survival \\
(days)
\end{tabular}

Endothelial cells are of Lew origin.

Endothelial cell labeling. Endothelial cells were treated with trypsin at $25^{\circ} \mathrm{C}$. The cells were then centrifuged $(400 \mathrm{~g})$ for 5 minutes. The resuspended cells were labeled with PKH-26 intercalating dye (Zynaxis Cell Science Inc., Malvern Pa.). This dye is excited at $550 \mathrm{~nm}$ and emits fluorescent (orange) light at $560 \mathrm{~nm}^{7}$

\section{Results}

In this strain combination (Lew $\times \mathrm{BN} \mathrm{F}_{1} \rightarrow$ Lew) untreated Lew rats reject the allografts in $7 \pm 1$ days $(n=5)$ (Table I). Allografts pretreated with endothelial cells survive for $12 \pm 2$ days $(p<0.05)(n=$ $5)$. Therapeutic cyclosporine ( $15 \mathrm{mg} / \mathrm{kg}$ per day for 7 days) resulted in indefinite graft acceptance $(n=$ $5),{ }^{8}$ but subtherapeutic cyclosporine $(1.5 \mathrm{mg} / \mathrm{kg}$ per day for 7 days) did not alter survival ( $7 \pm 1$ days) $(n=5)$, nor did perfusion of the allografts with Krebs-Henseleit buffer alone. The combination of $3 \times 10^{6}$ endothelial cells, of recipient origin, and subtherapeutic cyclosporine resulted in long-term survival of the heart transplants ( $>100$ days) $(n=$ 7).

So that we could determine whether these Lew long-term survivors were tolerant to the allograft antigens, they were transplanted (day 30 ) with splitthickness skin grafts of Lew $\times \mathrm{BN} \mathrm{F}_{1}$ origin and simultaneous contralateral split-thickness skin grafts of a third-party (Dark Agouti-RT1 ${ }^{\text {av1 }}$ [DA]) origin. All split-thickness skin grafts were rejected at $15 \pm$ 3 days $(n=3)$. There was no significant difference in the fate of the DA split-thickness skin grafts when compared with the Lew $\times \mathrm{BN} \mathrm{F}_{1}$ split-thickness skin grafts. Control experiments in Lew rats pretreated with subtherapeutic cyclosporine, but not a cardiac transplant, were performed and all split-thickness skin grafts were rejected at $17 \pm 2$ days $(n=3)(p>$ $0.05)$. The presence of the split-thickness skin grafts did not alter the fate of the heart grafts. In addition, mesenteric lymph node cells harvested from Lew long-term (50 days) survivors were cultured for 9 days with irradiated lymph node cells of donor $\left(\right.$ Lew $\left.\times \mathrm{BN} \mathrm{F}_{1}\right)$ and third-party (DA) origin $(n=3)$ (see Figs. 1 and 2).

The unidirectional mixed lymphocyte culture in Fig. 1 indicates day 8 as the point of maximum proliferation when responding cells were from untreated Lew rats regardless of the source of irradiated stimulators. However, in Fig. 2, day 6 represents the point of maximum proliferation in responding cells of transplanted Lew origin when stimulation was provided by irradiated (Lew $\times \mathrm{BN}$ $F_{1}$ ) cells. Furthermore, the stimulation index scale on the ordinate axis is much lower in Fig. 2 than in Fig. 1, indicating moderate nonspecific immunosuppression in the transplanted host. Mitogenic stimulation of lymph node cells from either control or experimental Lew rats, with $0.5 \mu \mathrm{g} / \mathrm{ml}$ Concanavalin A (Boehringer Mannhein GmbH, Mannheim, Germany) demonstrated a peak proliferative response after 36 hours or 72 hours of culture, respectively. There was no significant difference, however, in the stimulation index $(p>0.05)$ (data not shown).

The fate of the perfused endothelial cells was determined by labeling the cells $(n=5)$ before injection, with PKH 26 dye, a fluorescent membrane linker. Because histologic frozen sections of heart allografts will spontaneously fluoresce light (green) in the $480 \mathrm{~nm}$ range (autofluorescence of macrophages and vessel elastin), fluorescent light emission at a different region of the spectrum $(550 \mathrm{~nm})$ is required for successful trafficking studies (Figs. 3 and 4). Fluorescent label is partitioned between daughter cells as a parent cell divides, justifying the 

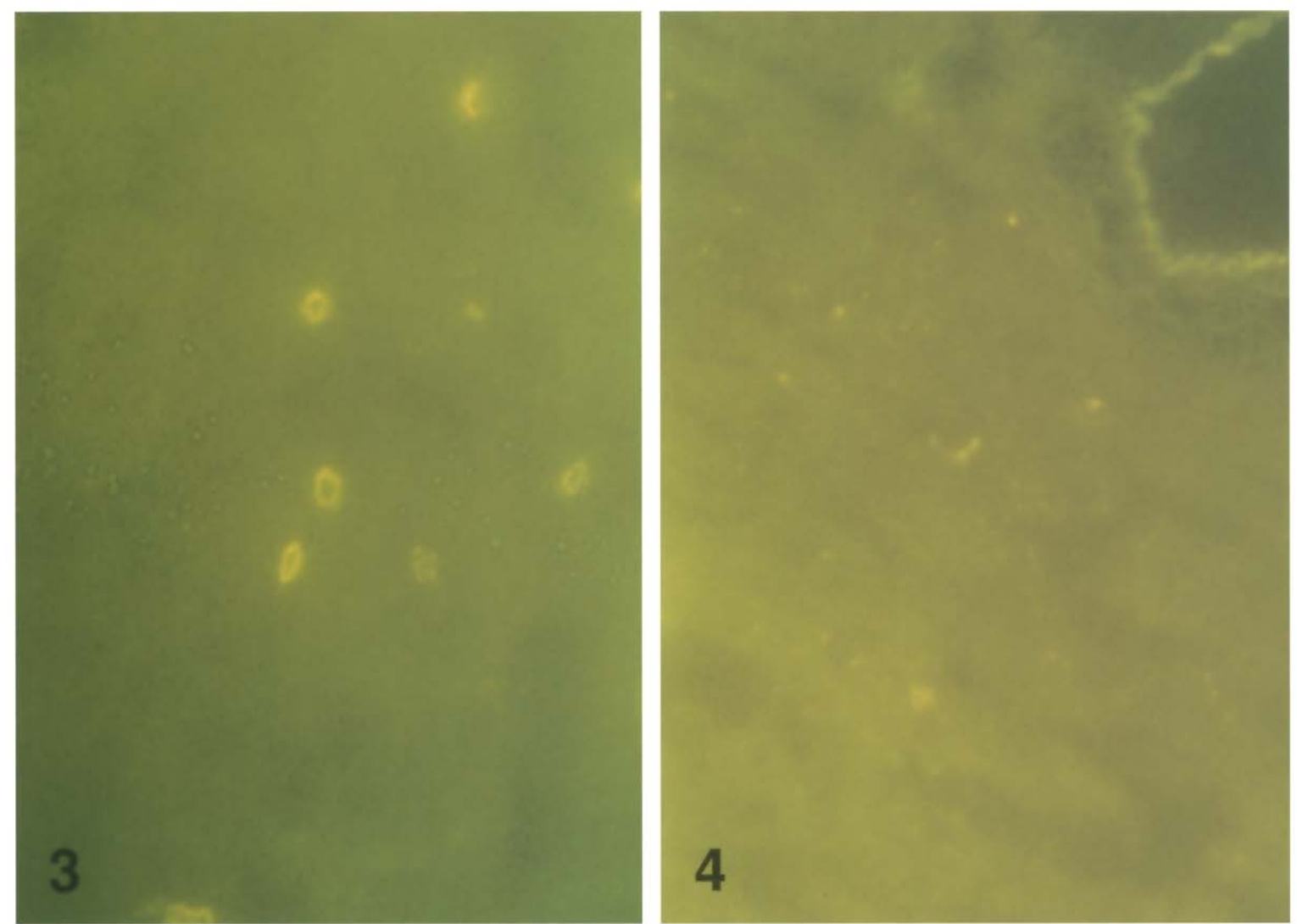

Figs. 3 and 4. Endothelial cell trafficking studies $(n=5)$. Labeled endothelial cells with PKH 26 dye (orange) are seen to line intermyocardial capillaries 20 minutes after antegrade injection into the coronary arteries (Fig. 3). These frozen histologic sections were photographed with a fluorescent light at $550 \mathrm{~nm}$. Labeled daughter cells continue to fluoresce, with a weaker signal, in the same anatomic location 15 days after transplantation (Fig. 4). Note the autofluorescence of the elastin of a large blood vessel (green).

smaller signal in Fig. 4 (15 days after transplantation) when compared with Fig. 3 (20 minutes after injection).

\section{Discussion}

This simple reproducible technique not only facilitates long-term survival in this rodent heterotopic cardiac allograft model but reduces the requirement for pharmacologic immunosuppression. We hypothesize that the seeding of donor organs with endothelial cells of recipient origin reduces immunogenicity by either masking the expression of the class II MHC molecules or causing up-regulation or downregulation of $\mathrm{MHC}$ or cell adhesion genes (or both) in the donor endothelium.

It has previously been shown that the donor endothelial cell is immunogenic and its immunogenic capacity is directly proportional to the extent of class II MHC antigen expression on the cell surface. ${ }^{9}$ The role of adhesion molecules in allorejection, however, is unclear.

Normally, specialized microvascular endothelial cells promote leukocyte extravasation into lymphoid structures, a process that requires reciprocal recognition of leukocyte/endothelial cell adhesion molecules. ${ }^{10}$ In this way, endothelial cells can regulate the normal patterns of systemic leukocyte migration. Endothelial cells also regulate inflammatory leukocyte infiltration, albeit by different sets of adhesion molecules. ${ }^{11,12}$ These leukocyte/endothelial adhesion systems are not allelic and can operate across allogeneic barriers. As a result, inflamed allograft endothelium can interact with host leukocytes to promote interstitial migration via mechanisms that are not associated with compromised vascular integrity. Consequently, the microvascular endothelium 
of rejecting allografts is an active participant rather than a passive target of the rejection process.

Leukocyte/endothelial adhesion systems associated with inflammation and cell-mediated immunity that have been identified include LFA-1/ICAM$1,{ }^{12,13}$ CD2/LFA-3 ${ }^{12,}{ }^{13}$ VLA-4/VCAM- $1,{ }^{13}, 14$ and CDw49e/fibronectin. ${ }^{14}$ Antibodies to ICAM-1 and LFA-1 interfere with cardiac allograft rejection in mice. ${ }^{15} \mathrm{We}$ are presently investigating the relative roles of MHC and cell adhesion molecules in our model.

We do know that this phenomenon does not represent tolerance. First, the in vitro proliferation of lymphocytes harvested from transplanted rats, when stimulation was provided by donor-specific antigen, was not abrogated in comparison with control values. Second, split-thickness skin grafts of donor origin were rejected within control times. In the context of the mixed lymphocyte culture data, this latter observation with split-thickness skin grafts probably does not represent a case of tissue-specific antigenicity. ${ }^{16}$

The fact that these endothelial cells persist and proliferate in the allograft vascular tree suggests that the immunomodulation is a dynamic process. We are presently investigating techniques to transfect these endothelial cells with a "tag" such that trafficking studies may be performed beyond 15 days.

The results have obvious clinical applications. For instance, all prospective recipients of vascularized allografts (i.e., heart, liver, kidney, lung, and pancreas) could have autologous endothelial cells in culture. Just before transplantation the cadaveric donor allograft, washed with University of Wisconsin preservation solution, would be perfused with these cultured cells. These efforts may reduce the requirement of host immunosuppression and its associated complications. Furthermore, this system could easily be applied to a model of xenotransplantation.

We thank S. K. Williams, PhD, and J. B. Moying, MS, University of Arizona, for their assistance in the technique of preparation of microvessel endothelium.

\section{REFERENCES}

1. Starzl TE, Demetris AJ, Trucco M, et al. Cell migration and chimerism after whole-organ transplanta- tion: the basis of graft acceptance. Hepatology 1993; 17:1127-52.

2. Disney APS. Complications of immunosuppressive therapy in transplantation. 1. Neoplasia and infection. Med J Aust 1992;157:262-4.

3. Russ GR. Complications in immunosuppressive therapy in transplantation. 2. Specific immunosuppressive agents. Med J Aust 1992;157:264-6.

4. Sedmak DD, Orosz CG. The role of vascular endothelial cells in transplantation. Arch Pathol Lab Med 1991;115:260-5.

5. Tyers GFO, Morgan HE. Isolated heart perfusion techniques for rapid screening of myocardial preservation methods. Ann Thorac Surg 1975;20:56-65.

6. Ono K, Lindsey ES. Improved technique of heart transplantation in rats. J Thorac Cardiovasc SuRg 1969;57:225-9.

7. Horan PK, Slezak SE. Stable cell membrane labelling. Nature 1989;340:167-8.

8. Tilney NL, Padberg WM, Lord RH, Araneda D, Strom TB, Kupiec-Weglinski JW. Synergy between subtherapeutic doses of cyclosporine and immunobiological manipulations in rat heart graft recipients. Transplantation 1988;46:1225-8.

9. Ferry B, Halttunen J, Leszczynski D, et al. Impact of class II Major Histocompatibility Complex antigen expression on the immunogenic potential of isolated rat vascular endothelial cells. Transplantation 1987; 44:419-503.

10. Duijvestijn A, Hamann A. Mechanisms and regulation of lymphocyte migration. Immunol Today 1989; 10:23-8.

11. Pober JS, Cotran RS. The role of endothelial cells in inflammation. Transplantation 1990;50:537-44.

12. Makgoba MW, Sanders ME, Shaw S. The CD2LFA-3 and LFA-1-ICAM pathways: relevance to Tcell recognition. Immunol Today 1989;10:417-22.

13. Hughes CC, Savage DO, Pober JS. The endothelial cell as a regulator of T-cell function. Immunol Rev 1990;117:85-102.

14. Elices MJ, Osborn L, Takada Y, et al. VCAM-1 on activated endothelium interacts with the leukocyte integrin VLA-4 at a site distinct from the VLA-4/ fibronectin binding site. Cell 1990;60:577-89.

15. Isobe $\mathbf{M}$, Yagita $\mathbf{H}$, Okumura $\mathrm{K}$, et al. Specific acceptance of cardiac allograft after treatment with antibodies to ICAM-1 and LFA-1. Science 1992;255: 1125-7.

16. Bildsoe P, Sorenson BF, Pettirossi O, et al. Heart and kidney transplantation from segregating hybrid to parental rats. Transplant Rev 1970;3:36-9. 